\title{
Nick Moore, his information policy matrix, with a bibliometric analysis.
}

\author{
MUIR, A. and OPPENHEIM, C.
}

2017

This author accepted manuscript is deposited under a Creative Commons Attribution Non-commercial 4.0 International (CC BY-NC) licence. This means that anyone may distribute, adapt, and build upon the work for non-commercial purposes, subject to full attribution. If you wish to use this manuscript for commercial purposes, please contact permissions@emerald.com 
Library Management

emerald

Library Management

NICK MOORE, HIS INFORMATION POLICY MATRIX, WITH A BIBLIOMETRIC ANALYSIS

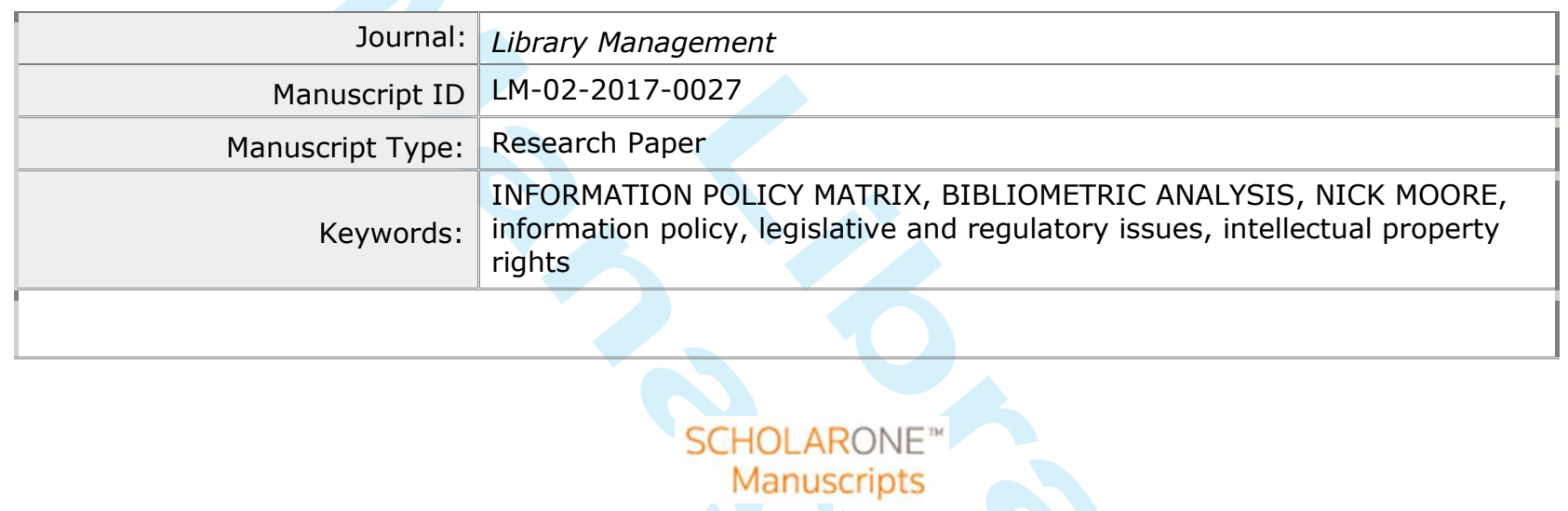


NICK MOORE, HIS INFORMATION POLICY MATRIX, WITH A BIBLIOMETRIC ANALYSIS

\author{
Adrienne Muir \\ Robert Gordon University, \\ Garthdee Road \\ Aberdeen \\ AB10 7QE \\ a.muir3@rgu.ac.uk* \\ and \\ Charles Oppenheim \\ c.oppenheim@rgu.ac.uk
}

\title{
Introduction
}

One of Nick Moore's contributions to library and information research and practice was the development of a matrix to be used for analysing different countries' information policies. Conceptions of information policy have changed over time, from managing and disseminating government information to the role and use of information in organisations and society more generally. Orna (2008) has provided an overview of the historical development of information policy, which became important to governments in the late 1970s, whilst Mahon (1989) reviewed developments in European information policy up to the late 1980s. Information policy became a more widely prominent topic during the 1990 s, coinciding with discussions around the information age and the development of information and knowledge based societies

Moore's work in information policy really started when he joined the independent Policy Studies Institute (PSI) in 1989 and secured funding from the then British Library Research and Development Department (BLR\&DD) to write a book on information policy in the UK. As Moore (2012) explained in a presentation, the aim of the information policy work at PSI was "Making the bullets for others to fire" by carrying out research to inform the policy making process. Early on, Moore (1990) identified four broad categories of issues to be considered in information policy analysis:

- legislative and regulatory issues (such as intellectual property rights, data protection, privacy, freedom of information, liability for information as well as information as a tradeable commodity and regulations relating to that, transborder data flows, self-regulation by the information industry, and standardization);

- macroeconomic issues, such as defining and analysing the size and development of a country's information sector, comparing it to other countries, and investment in all aspects of the sector;

- organisational issues (such as use of information as a resource, the link between information and productivity, management implications, implications for skill sets, and the development of new career possibilities); and social issues, including information for 
consumers, quality of information, meeting unmet needs, information literacy, role of libraries and information services, and information rich versus information poor.

Moore developed his information policy matrix for both conceptualisation and analysis purposes. In his 2012 presentation noted earlier, Moore explained that information policy can be analysed at three different levels: Industrial, Organizational and Societal. Moore was not dogmatic about the cross-cutting elements of his matrix, as he used slightly different forms at different times as he refined his thinking, and also perhaps in response to information-related developments over time. So for example, in 1993, Moore employed the following matrix:

\begin{tabular}{|l|l|l|l|l|l}
\hline & IT & $\begin{array}{l}\text { INFORMATION } \\
\text { MARKETS }\end{array}$ & $\begin{array}{l}\text { INFORMATION } \\
\text { ENGINEERING }\end{array}$ & $\begin{array}{l}\text { HUMAN } \\
\text { RESOURCES }\end{array}$ & $\begin{array}{l}\text { LEGAL AND } \\
\text { REGULATORY }\end{array}$ \\
\hline INDUSTRIAL LEVEL & & & & & \\
\hline $\begin{array}{l}\text { ORGANISATIONAL } \\
\text { LEVEL }\end{array}$ & & & & & \\
\hline SOCIAL LEVEL & & & & &
\end{tabular}

Table 1: 1993 Information Policy Matrix (Moore, 1993).

The legal and regulatory element of the matrix has always been present. An element relating to the skills required to effectively handle information is also always present, whether it is termed "human resources" or "skills". The element relating to the supporting infrastructure has changed to reflect the development of technologies and the widespread presence of networks. The element "information engineering" appeared in the 1993 version of the matrix, but not in later versions. Moore (1993, p.284) defined information engineering as "the full range of activities and processes that are designed to improve the management and use of information" He may have decided upon reflection that information engineering is really part of information infrastructure, rather than as a totally separate entity from information and technologies. In addition, information engineering capability could be considered to be part of human resource requirements. The information markets element remains

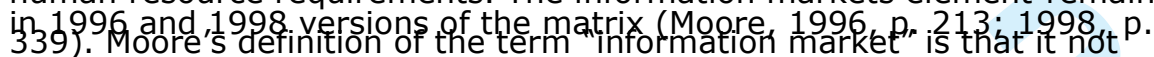
only encompasses commercial trading of information, but can also include where information is provided "free at the point of use", for example, in libraries and other public or voluntary sector information and advice services.

The matrix presented by Moore in 2012 appears to reflect a further refinement. "Information markets" has disappeared from the cross-cutting elements and only the infrastructural, legal and regulatory and skills elements remain. IT has become ICT and Networks, explicitly reflecting developments in more recent years. The names of the three levels of policy making have been adjusted slightly. The change from "Industrial Level" to "Information Sector" could account for the removal of "Information Markets" as this latter term seems to encompass all models of information exchange. It seems this simplified and updated version of the matrix, shown below first appeared in 2012. 


\begin{tabular}{|l|l|l|l}
\hline & $\begin{array}{l}\text { ICT AND } \\
\text { NETWORKS }\end{array}$ & $\begin{array}{l}\text { LEGAL AND } \\
\text { REGULATORY }\end{array}$ & SKILLS \\
\hline INFORMATION SECTOR & & & \\
\hline INFORMATION IN ORGANISATIONS & & & \\
\hline INFORMATION IN SOCIETY & & &
\end{tabular}

Table: 2012 Information Policy Matrix (Moore 2012)

Whatever form of Moore's matrix they use, researchers can use it by analysing each cell in the matrix to identify policies that are already in place, and policies that are needed to address perceived weaknesses. This would be an appropriate approach when analysing national information policies. Given the pervasiveness of information and the overlaps and interdependencies between the nine information dimensions in the $3 \times 3$ matrix the matrix probably works best when all cells are investigated, even if the focus of the research is narrow (for example examining policies related to improving scholarly communication or undertaken by a small team of individuals with experience and knowledge of the current situation in the country, the policies in place, and of formulating and implementing policy. Brainstorming ideas in a freeranging discussion works best when using Moore's matrix. One of us (CO) worked with Moore and others in a visit to China in $1993^{1}$ to assist the Chinese government develop its information policy priorities, and found the experience of working on the matrix both enjoyable and enlightening. Comparisons between countries, or focusing on particular industries or market sectors can of course also be carried out using the matrix.

When Moore first developed his matrix, the internet, social media, wifi, the Cloud, machine learning and artificial intelligence, mobile phones, etc., either did not exist at all, or were at an extremely early stage of development. Nonetheless, his matrix, particularly in its latest iteration, is sufficiently flexible to accommodate all those new developments and future anticipated developments, and many of the issues highlighted in the use of Moore's matrix are relevant key issues today. For example, all the key developments identified in a very recent information policy briefing paper (Anon, 2017) are all capable of being analysed using Moore's matrix. The matrix is also a useful tool for comparison between countries, not only to highlight gaps in policy but also to highlight differences in approach. Analysts can then evaluate the reasons for and impact of the differences.

The purpose of this article is to remind readers of Moore's information policy matrix and note how it has been employed by Moore. We have combined that with a small bibliometric study on Moore's overall impact on other scholars. One would expect that his intuitive matrix would be widely employed by researchers and policy-makers throughout the world. Yet, as will be shown, an analysis of the literature suggests that Moore's information policy matrix is rarely used. We consider possible reasons for this, drawing on the information policy literature and evaluating the

${ }^{1}$ This was the British Council/Aslib "Chinese Information Policy and Strategy to 2000" symposium, held in Beijing, 6-11 September 1993. 
relative value of different approaches to analysing information policies in comparison to Moore's matrix.

\section{Has the matrix been used?}

One problem with undertaking this research has been the uncertainty of when Moore first developed his policy matrix, and when he first wrote about it. It seems the first description of his thinking on information policy analysis was in his 1990 PSI pamphlet, followed by several journal articles by. Moore in the years following. Although the pamphlet, which quite possibly was for internal use only; has been cited once, approvingly

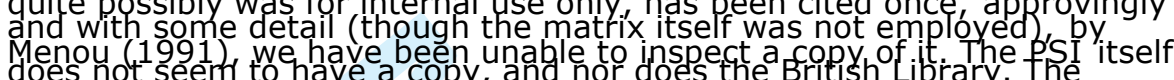
British Library-funded information policy book by Moore and Steele (1991) does not explicitly describe Moore's matrix, and indeed it makes no mention of any policy-analysing matrix. It may be that Moore developed his matrix in the course of carrying out the research and analysis for the book, but it was too late to include it in the work.

Moore (1993) set out and explained his policy matrix in a paper that he presented to the joint Aslib/British Council symposium mentioned above. The use of the matrix here was to introduce a method for presenting a set of suggestions for policy goals in China rather than evaluating the current policy situation. Another presentation, this time to the Workshop on the European Information Services Market, was published in 1996. In this case, the matrix was used to analyse the policy issues arising from a European Commission commissioned survey of the European electronic information market (Moore 1996). In another published conference paper, Moore (1997) discusses differences in approach to national information policy making. The policy matrix and analysis process is not discussed in the paper, but it may well have featured in the analysis that led to the conclusions on different models of policy making. Moore (1998) also used the matrix to discuss the UK policy landscape. Interestingly, in this paper Moore claims that the matrix was developed to assist the European Commission, but the citation to this comment he gives is to (Moore, 1993) relating to China. Given that Moore was awarded the large European Commission Information Market Observatory contract in the early 1990s, this remark may, nonetheless, be correct, i.e., he developed his matrix thanks to European Commission funding, but it is first described in the China paper. What is clear is that Moore has used his matrix in various ways: to analyse policy issues in one country and across a union of member states, as a framework to measure the current situation against a set of possible policy goals and to identify differences in values and approaches to policy making in different countries.

Moore clearly found matrices a helpful tool for analysing complex situations. For example, in Moore (2002) on models of social needs, he broke down the issues into a series of cells in a matrix, albeit with very different headings to his information policy matrix, whilst his analysis of information policies in East Asia (Moore, 1997), though not explicitly using 
his matrix, uses terms to break down his analysis that are in part based on his policy matrix.

To our surprise, the vast majority of post-1990 papers on national information policies have not used Moore's matrix. There have been few reviews of information policy methods; Browne's review of the field (Browne, 1997) mentioned, but failed to explore Moore's work. Rowlands' (1996) review, in contrast, does explore Moore's work and his matrix in some detail, but does not cite any outputs that have employed Moore's matrix. Orna's (2008) excellent review of both the USA and UK makes no mention of the tools used to analyse information policies. Oppenheim's $(1996)$ review of UK national information policy cites Moore and Steele, but the way he classifies the policies is not hased upon Moore's previpús policy analysis, which, though it bears some resemblances to Moore's, is very different in structure to it.

What about primary research outputs? We have selected just a few exemplars of such non-use of Moore's matrix. Middleton's (1997) review of Australian information policy does not use the matrix, Gomez-Barroso et al's (2008) review of European information policies makes no mention of the matrix, and similarly, Hernon's (1998) analysis of US information policy does not make use of his matrix; Shuler (2002) in his review of information policies in local governments makes no use of the matrix, whilst Priftis and Oppenheim (1999) acknowledged Moore's work in their study of Greek national information policies, but failed to use his matrix. Ma et al (2012) used a three level classification based on the information life cycle for their analysis of Chinese information policies, similarly, Zawiyah et al (2012) develop a classification approach to information policy analysis rather than a two dimensional matrix. Finally, our own series of research papers (Muir and Oppenheim 2002a, 2002b, 2002c, 2002 d) on national information policies did not employ the matrix.

Rowlands, Eisenschitz and Bawden (2002) recommend the use of frame theory for exploring the values underpinning policy making rather than mentioning the matrix, but this approach would be a method of analysis that could be compatible with use of the matrix.

Maxwell (2004) developed an information policy framework for analysing the politics of the USA's Digital Millennium Copyright Act. In this paper, he claims that Hernon and McClure (1987) were the first authors to call for the establishment of a discipline of information policy analysis, and that they developed initial models for such analysis in their book. As Maxwell notes, few researchers have followed this up by carrying out such policy analyses. The difficulty, he claimed, lies with the fact that the raw materials for such policy analyses most often appears in oral testimony, newspaper or journal articles and legislative reports - materials that resist easy analysis in part because of the bias of researchers. However, Maxwell does not explain why he thinks information policy researchers would be biased, and supplies no evidence of any such bias. Maxwell recommends content analysis for the extraction of textual documents and subsequent quantitative analysis of the text as a suitable method for information policy analysis. Maxwell then describes his own matrix, 
comprising two columns (Communal and Individual) with four crosscutting themes (called Sovereign, Transformation, Production, and Global) into which he populates the frequency of use of keywords associated with each cell of the matrix to see what were the most important themes emerging. The approach is thus very different from that of Moore, who populates his matrix by means of discussion and brainstorming amongst experts. Maxwell does not cite any of Moore's work, and, indeed, all the references to the background of information policy analysis in his article are to US sources. One of these works looks potentially relevant - a book chapter by Charles McClure et al entitled "Frameworks for studying federal information policies", which appeared in a 1989 book edited by Hernon et al entitled "United States government information policies". Hernortunatel and we have peen unable toget hold of either this book or the on their contents.

To conclude: although we are not dismissing the idea that Moore's matrix has been used, our literature searching failed to uncover an example of use of the matrix other than by Moore himself. We did, however, find two papers that use a matrix approach for analysing information policies and which predate Moore's work. Both are more complex in approach than Moore's. Karni (1983) developed a matrix with eight elements and six cross cutting dimensions. His elements included topics such as function, inputs, outputs, process, environment and human agents, and his dimensions were physical, operations, development, assurance, interface and evaluation. The primary purpose of his matrix was, it seems, for use by the private sector rather than by governments. Both Karni's paper, and Menou's (1985) similarly very complex information policy matrix naturally do not mention Moore's work, as they predate it, but it is possible that their work inspired Moore to develop a matrix that was more accessible and intuitive. We believe, however, that it is more likely that Moore developed his matrix quite independently of these earlier information policy matrixes, as his matrix papers do not cite any earlier work as providing him with the ideas for a matrix.

\section{Bibliometrics, information policy and Nick Moore}

The topic of information policy has not often been the subject of bibliometric studies. One notable example is Ian Rowlands' PhD thesis, which was later summarised in two journal articles (Rowlands 1999a; 1999b). Rowlands classified information policy research into seven broad headings, some of which map onto Moore's matrix, but some of which do not. They were: information management in government; information protectionism; public access to information; national and international frameworks; scientific and technical information policy; information infrastructure and regulation; and social implications of ICT. Using wellestablished co-citation techniques, Rowlands found, somewhat surprisingly, that Moore's research output was only associated with one of these fields, i.e., information infrastructure and regulation, which according to Rowlands covers "information industry and markets; political economy of information; manpower and training; public-private synergy; copyright and intellectual property; and information law and regulation", 
whilst he was not mentioned in the grouping entitled national and international frameworks, which Rowlands defines as covering "national and international policies and strategies; national libraries; international collaborations and agreements; and scientific and technical information". In an article based upon his thesis, Rowlands (1999a) noted that, based upon his document text collection of 771 articles published between 1972 and 1996, which was compiled from records in Social Sciences Citation Index, the structure and dynamics of the information policy journal literature diverges in several respects from typical social science literatures. He found that the information policy journal literature was characterised by very rapid growth, high immediacy (in Price's sense), rapid reception and ageing processes, and relatively low documentary scatter.

As part of the research we undertook in preparation of this article, we carried out a citation study on Moore, to assess which of his publications have been most cited, what subject areas these were focussed on, and, in particular, how influential his matrix for analysing information policies in different countries has been. The citation analysis was carried out between December 2016 and January 2017. We found there was a problem of inconsistencies in the way citations were recorded on the different databases we used, and it is therefore possible that the figures obtained are not $100 \%$ correct, but we believe they provide a good estimate of impact, and in particular, the relative importance of the numerous outputs that Moore published in his lifetime. The results also show just how widely variable the major citation databases are with their results of citation counts.

Based on our results, perhaps the most important (based on the possibly dubious assumption that "more citations" equals "more important") of Moore's papers regarding the use of his matrix is (Moore 1993).

Microsoft Academic Search (www.academic.microsoft.com)

Using this source, Moore's most highly cited output is his textbook How to do Research. This had received 202 citations at the time we checked The most highly cited of his papers that employed his matrix (Moore, 1998) was the $11^{\text {th }}$ most cited item in the list. It had received eight citations. Moore's most cited outputs according to this service are papers not relating to his information policy matrix. Using this service, Moore's $\mathrm{h}$ index ${ }^{2}$ is 9 .

Google Scholar (scholar.google.com)

Again using this resource, Moore's most cited work was How to do research with 367 citations. The most cited of his outputs using his matrix was (Moore, 1993), equal tenth with 27 citations.

Using this service, Moore's $\mathrm{h}$ index comes out at 17.

${ }^{2}$ For a concise review of the $\mathrm{h}$ index, its strengths and weaknesses, see https://en.wikipedia.org/wiki/H-index 
Web of Science

Using Web of Science, a much smaller data set was obtained. A search for Moore, N. as an author produced a large number of hits. When the data set was reduced down to social sciences and related areas, there were still many false drops, especially because of a very productive author called Niamh Moore. By checking individual titles, an analysis with reasonable accuracy was completed. On this basis, an article of Moore's entitled "Emerging employment market for librarians and information workers" had the most citations, with 13. His most cited matrix paper was (Moore 1993), equal $7^{\text {th }}$ with five citations.

Moore's $\mathrm{h}$ index is 6 using this source.

Some further comments on these results are worth making. They confirm the well known differences in results when undertaking citation searches using different search tools, with, as expected, the free service Google Scholar offering much higher citation, and $\mathrm{h}$ index scores than the charged-for Web of Science or indeed the free Microsoft Academic Search. This result is not surprising, as such findings are well known from other studies. It was also not surprising that Moore's standard textbook, How to do research, is heavily cited, as this is consistent with other studies that show that publications describing basic methods or techniques receive more citations than possibly more ground-breaking outputs. What is perhaps more surprising is the lack of correlation of individual items in the three sets of results. One might have expected that even though the totals for each service would differ, that in general the most highly cited items in one list would also be the most highly cited in another. In practice, however, this was not the case.

We also found that in terms of his research outputs, Moore's work on the library and information workforce in the UK is cited much more than his work on national information policies, and, in particular, his information policy matrix has not been widely citéd deśpite its simplicity and ease of use. Due to lack of time, we did not investigate the papers that cited Moore's matrix any further.

We also carried out searches on the title words "National Information Policy" on Web of Science and on Science Direct. The former produced 46 hits, the latter 14 hits. None of the items was authored by Moore. The low number of items found (in each case the search was 1960 to date) indicates a surprisingly low level of scholarly interest in the topic. Of course, as we were searching for the phrase "national information policy" in the title, other potentially relevant items but without that phrase in the title were overlooked. Of the papers we did find in the searches, only one, by Menou (1991), specifically referred to Moore's matrix.

We carried out a similar search for "national information policy" in the title using Library Literature and Information Science, an Ebsco abstracting service. We found 52 items, none of which were by Moore, but one item, by Haines (2002) states that much of the work carried out by her team 
was based on research undertaken by Moore using his matrix. At the time this article was written, Haines was head of the UK's Library and Information Commission, and one of its tasks was to develop a national information policy for the UK. Unfortunately, the Commission, after various mergers and changes of name, was abolished in 2012 by the UK Government, and in any case failed to convince the UK Government to adopt a pro-active national information policy. Overall, we found that Moore was the only person who used his matrix for information policy analysis. Examples include his (1998), (1991a), (1991b), (1996) (1998) papers, and of course (Moore, 1993).

\section{Conclusions}

Two things have emerged from our exploration of Moore's contribution to information policy analysis. Firstly, it is clear that there have been two quite separate trains of research, one in the USA and one in Europe, and that neither party seems to be aware of the other party's work. Secondly, and focusing on the UK and European research, we are puzzled that the papers we inspected that report information policy analyses make no mention of Moore's work. Without further research, it is difficult to know the reasons and therefore we are only able to speculate. It could be argued that Moore's matrix is too simplistic for such a complex topic as information policy, but it may also be the case that there is a lack of awareness of how the matrix can be used in policy analysis. We were unable to find any rigorous academic papers explaining the theoretical basis of the policy matrix authored by Moore; his papers addressing the matrix were general descriptions of its application, published versions of conference papers or other types of presentation. In these publications, Moore described the matrix, reported the findings of his analyses or suggested policy goals. We were unable to find any more theoretical or methodological papers where Moore explained how to go about policy

analysis using his matrix or how he arrived at suggestions for policy goals. This may be the reason that academic researchers have not used the matrix. As pointed out at the beginning of this paper, Moore developed his matrix in the context of providing information to influence the policy agenda rather than as a contribution to the theory of policy studies. Scholars in the information field who have explored theoretical approaches to understanding information policy include Rowlands, Eisenschitz and Bawden (2002), who, as noted above, applied frame theory to the issue of how to make "the value systems that underpin our understandings of information policy more explicit", but such papers are rare.

In conclusion, perhaps because of Moore's failure to provide a strong theoretical basis to his matrix, we believe it is an under-used, but potentially valuable method of analysing information policies. 


\section{References}

Anon (2017), "What will happen to the information sector in 2017?", https://findwise.com/blog/information-2017/

Browne, M. (1997), "The field of information policy I: fundamental concepts", Journal of Information Science, 1997, Vol. 23, No. 4, pp. 261275.

Gomez-Barroso, J.L., Feijoo, C. and Karnitis, E. (2008), "The European policy for the development of the information society: the right path?", Journal of Common Market Studies, Vol. 46, No. 4, pp. 787-825. Haines, M.P. . (2000) "National information policy' and national network development", Multimedia Information and Technology, Vol. 26, No. 1, pp. 52-59.

Hernon, P. (1998), "Information dissemination as reflected in US government information policy and practice, The Internet and Higher Education, Vol. 1, No. 1, pp. 59-81.

Hernon, P. and McClure, C.R. (1987), Federal information policies in the 1980s, Ablex Publishers (1987)

Hernon, P., C.R. McClure and H. Relyea (Eds), United States government information policies, Ablex Publishers (1989).

Karni, R. (1983), "A methodological framework for formulating information flow", Information and Management, Vol. 6, No. 5, pp. 269280.

Ma, F. et al (2012), "A study on the structure of the Chinese information policy domain framework", Journal of Information Science, Vol. 38, No. 1, pp. 52-63.

Mahon, B. (1989), "Developments in European information policy", Perspectives in Information Management, Vol. 1, pp. 63-87.

Maxwell, T.A. (2004), "Mapping information policy frames: the politics of the Digital Millennium Copyright Act", Journal of the American Society for Information Science and Technology, Vol. 55, No. 1, pp. 3-12.

Menou, M.J. (1985), "An information system for decision support in national information policy-making and planning", Information Processing and Management, Vol. 21, No. 4, pp. 321-361.

Menou, M.J. (1991), "National Information Policy in the less developed countries: an educátional perspective", International Library Review, Vol. 23, No. 1, pp. 49-64.

Middleton, M. (1997), "Information policy and infrastructure in Australia", Journal of Government Information, Vol. 24, No. 1, pp. 9-25.

Moore, N. (1990), Information policy: a discussion paper of the Policy Studies Institute's information policy programme, Policy Studies Institute, London.

Moore, N. and Steele, J. (1991), Information intensive Britain [BLR\&D Report 6038], Policy Studies Institute, London.

Moore, N. (1991), "How fortune can be opposed", International Forum for information and documentation, Vol. 16, No. (1), pp. 3-5.

Moore, N. (1991), "Policies for an information intensive Britain", Bulletin of the American Society for Information Science, No. 17 (April/May), pp. $10-11$.

Moore, N. (1993), "Information policy and strategic development: a framework for the analysis of policy objectives", Aslib Proceedings, Vol. 45 , No. $11 / 12$, pp. 281-285. 
Moore, N. (1996), "Policy issues in the multimedia age", Journal of Information Science, Vol. 22, No. 3, pp. 213-219.

Moore, N. (1997), "The information policy agenda in East Asia", Journal of Information Science, Vol. 23, No. 2, pp. 139-147.

Moore, N. (1998), "The British national information strategy", Journal of Information Science, Vol. 24, No. 5, pp. 337-345.

Moore, N. (2002), "A model of social information need", Journal of Information Science, Vol. 28, No. 4, pp. 297-303.

Moore, N. (2012), Making the bullets for others to fire: LIS DREaM 3 [online video of a paper presented to LIS DREAM Conference]. 30 January. Available from https://vimeo.com/36106962 [Accessed 12 January 2017].

Muir A and appenheim, C: (2002a) "National Information Policy Information Science, Vol. 28, No. 3, pp. 173-86.

Muir, A. and Oppenheim, C. (2002b), "National Information Policy developments worldwide. II: Universal access - addressing the digital divide", Journal of Information Science, Vol. 28, No. 4, pp. 263-73. Muir, A. and Oppenheim, C. (2002c), "National Information Policy developments worldwide. III: e-commerce, Journal of Information Science, Vol. 28, No. 5, pp. 357-374.

Muir, A. and Oppenheim, C. (2002d), "National Information Policy developments worldwide. IV: Copyright, freedom of information and data protection", Journal of Information Science, Vol. 28, No. 6, pp. 467-81. Oppenheim, C. (1994) "Are national information plans useful?", Alexandria, Vol. 6, No. 2, pp. 133-43. Oppenheim, C. (1996), "An agenda for action to achieve the information society in the UK", Journal of Information Science, Vol. 22, No. 6, pp. 407-421.

Orna, E. (2008), "Information policies yesterday, today, tomorrow", Journal of Information Science, Vol. 34, No. 4, pp. 547-565.

Rowlands, I. (1996), "Understanding information policy: concepts frameworks and research tools", Journal of Information Science, Vol. 22, No. 1 , pp. 13-25.

Priftis A and Oppenheim, C."(1999), "Development of a nationa information policy in Greéce", Information Development, Vol. 15, No. 1, pp. 32-43.

Rowlands, I. (1996), "Understanding information policy: concepts, frameworks and research tools", Journal of Information Science, Vol. 22, No. 1, pp. 13-25.

Rowlands, I. (1998), "Some compass bearings for information policy orienteering", Aslib Proceedings, Vol. 50, No. 8, pp. 230-237. Rowlands, I. (1999a), "Patterns of author co-citation and information policy: evidence of social, collaborative and cognitive structure", Scientometrics, Vol. 44, No. 3, pp. 533-546.

Rowlands, I. (1999b), "Patterns of scholarly communication in information policy: a bibliometric study", Libri, Vol. 49, No. 2, pp. 59-70.

Rowlands, I., Eisenschitz, T. and Bawden, D. (2002), "Frame analysis as a tool for understanding information policy", Journal of Information Science, Vol. 28, No. 1, pp. 31-38.

Shuler, J.A. (2002), "Information policies of local governments", Journal of Academic Librarianship, Vol. 28, No. 4, pp. 244-247. 
"What will happen to the information sector in 2017?", available at https://findwise.com/blog/information-2017/ (accessed 12 January 2017).

Zawiyah, M. et al, (2010), "Classification of issues underlying the development of information policies", Information Development, Vol. 26, No. 3, pp. 204-213. 